Global Journal of Arts, Humanities and Social Sciences

Vol.7, No. 5, pp.13-24, May 2019

Published by European Centre for Research Training and Development UK (www.eajournals.org)

\title{
THE DESTINIES OF AFRICANS IN THE MODERN WORLD ARE HINDERED BY SELFISH LEADERS (MATT. 20:24-28)
}

\author{
Ezeogamba Anthony \\ Chukwuemeka Odumegwu Ojukwu University, Anambra State, Nigeria
}

\begin{abstract}
Africa as a nation stands out as one of the cradles of life and civilization but when one looks around today one discovers that Africa has become the dumping ground of used products from Europe and America and to save life, one must travel to get adequate medical attention. Hospitals, schools, road networks, modern mass communication equipments, job opportunities, scholarship schemes, electricity are majorly in shambles or epileptic. When one visits some institutions of higher learning as well as hospitals outside the shores of Africa, one discovers that experts in various fields working in them are from Africa. One of the things migration of the young from Africa to Europe and America has taught us is that African children can compete favourably with their European and American counterparts when placed under the same condition. Hence, it is not that Africans are not gifted intellectually, they are but African's intellectual prowess has not been adequately harnessed as a result of the actions and inactions of their leaders. This proves that there is nothing wrong with African soil, water, air and vegetation. The problem is actually perpetuated daily by old, selfish, visionless and uncharismatic leaders in Africa. When such leaders are on seat, the destinies of their citizens are daily suppressed knowingly or unknowingly. This study aims at showing that African underdevelopment lies in the hands of selfish and sit-tight leaders. Jesus in the above chapter and verses of Matthew urges that anyone who will present himself to be a leader must be the servant of others. The desire of a servant leader centers on how to help all citizens realize their destinies. This study adopted the historical critical exegesis as well as library research as her methodology to arrive at her conclusions. This study argues that if present crop of leaders in Africa were to be selfless and charismatic, Africa will be the envy of the whole world. Significantly, this study will be of immense benefit to Africans and indeed the whole world.
\end{abstract}

KEY WORDS: Destiny, Leader, Selfish

\section{INTRODUCTION}

Africa has 54 countries according to United Nations official statistics and Nigeria is still regarded as the giant of Africa with assumed population of 200,962,417. Assumed because it is more than ten years now Nigeria had her census and there is no doubt that this is as a result of bad leadership. The two countries that are somehow closer to Nigeria in population are Ethiopia with a population of $110,135,635$ and Egypt with a population of 101,168,745. The least populated

Print ISSN: 2052-6350(Print), Online ISSN: 2052-6369(Online) 
country in Africa is Seychelles of Eastern Africa with a population of 95, 702. ${ }^{1}$ These African countries are immersed in backwardness and perennially answers 'developing countries' because of her numerous visionless, despotic and clueless administrators whose major desires can be summed up on how to perpetuate themselves in the office. Some of them change the constitution to suit their inordinate desires. They seem not to be interested in eradicating the problem of Africa from the root like paucity of modern infrastructure as well as educational and health institutions are not on the priority list of African leaders. Were these to be taken care of every other thing would follow systematically.

\section{African Leaders and Their offices}

In Africa, we have leaders who have really over stayed, put differently, there are very long serving leaders in Africa and when a leader stays like that he becomes insensitive and unproductive. As at November 2017 these are the longest serving leaders in Africa and they include: Teodoro Obiang Nguema Mbasogo of Equitoral Guinea who have already ruled for thirty eight (38) years; Robert Mugabe of Zimbabwe ruled for thirty seven (37) years; Paul Biya of Cameroon has ruled for thirty five (35) years; Denis Sassou Ngueso of the Republic of Congo has piloted the affairs of his country for thirty three (33) years; Yomeri Museveni of Uganda has ruled for thirty one (31) years, he even had constitution amended so as to allow him to have an unlimited presidential term; Omar al-Bashir of Sudan has been at the helm of affairs of his country for thirty (30) years judging from 1989 he assumed office. If not for the agitations of his country men and women he would have continued to be in the office till today. April 2019 is a month and year Omar al-Bashir will never forget in his life. Before Teodoro Obiang Nguema Mbasogo emerged as the longest serving president in the world, it was Moammar Gaddafi of Libiya who used to be the longest serving president in the whole world, but with his demise in 2011, Teodoro took over. Hence, Africa is home to more than half of the top 20 longest-serving political leaders in the world. They've flouted election laws in all ramifications. ${ }^{2}$ In the above countries people are being killed daily, but these leaders remained unperturbed.

When one considers the age of these leaders, one will also discover that age is not on their favour. There is an age that reduces one's productivity and some of these African leaders are hovering in such an age. For instance, Teodoro Obiang Nguema Mbasogo is 76 years old; Paul Biya is 86 years old; Denis Sassou Ngueso is 75 years old; Yomeri Museveni is 74 years old; Omar al-Bashir is 75 years old. It is most certain that it is in Africa that leaders struggle to die in office as president and at the same time unproductive. "The average age of the 15 oldest African leaders is 77, compared to 52 for the world's ten most-developed economies. Could this be one of the major

\footnotetext{
${ }^{1}$ United Nations, Official Statics (www.worldometers.info, 2019). Retrieved on 23/03/2019

${ }^{2}$ News Home, African's Political Leaders Some of the World's Longest Serving, (mobile.abc.net.au, 2017). Retrieved on $23 / 03 / 2019$.
} 
reasons for African's under-development?"3 If not for their selfishness and the thought that no one can do it better than them syndrome, they would have retired and give way to younger people with better idea and who can still interact with modern environment and equipment so as to improve the lot of their people.

A closer look reveals that Tunisian president Beji Caid Essebsi is the oldest president in Africa, he happens to be 91 years and is still serving as president. He is closely followed by Paul Biya as already stated above. President of Sao Tome and Principe, Manuel Pinto da Costa, 81 years old and ranks third oldest president. He is of the same age with Abdelaziz Bouteflika of Algeria. Muhammadu Buhari of Nigeria is officially 75 years old, the writer's own president, ranks number eleven in Africa. ${ }^{4}$ It is a fact that some Nigerians contest his actual age. Buhari has recently been elected to rule for the next four years. The implication is that if everything being equal he will leave office at the age of 79. Every Nigerian knows that it is not easy for him to be everywhere and also carry the burden associated with leadership today but how it will be tomorrow no one knows. Nigerians are crying and lamenting because of hard economic situation and senseless wasting of human life and the president looks helpless. Robert Mugabe of Zimbabwe, 94 years old would have wished to rule till death takes him if not that he was unceremoniously exited out of office. ${ }^{5}$ Everyone knows that the greatest problem of people of the above ages is forgetfulness or Alzheimer's disease that most often manifested in dementia and constant visit to hospitals as a result of cardiovascular disease, arthritis, type 2 diabetes, hypertension and others. It is a fact that generally and most often the older one becomes the friendlier one becomes to doctors and hospitals. For instance, President Buhari of Nigeria spent a total of 168 days in a London hospital between June 6, 2016 and August 19, 2017. Later, he made additional 4 days medical trip to the same London, yes London because the hospitals in Nigeria are not working efficiently to give him the required medical attention. So between May 2015 (his inauguration year) and May 2018 Buhari spent 172 days in a foreign hospital. One of his predecessors, late Umar Musa Yar'Adua spent 109 days on medical trip abroad. Hence, a reporter succinctly says, "President Buhari, more than late Yar'Adua has spent 172 days of his 1096 days in office seeking medical attention outside the country." ${ }^{6}$ Thus, beating all previous records. The agony of such a visit by these leaders is their inability to establish such a hospital in their country so as to help the poor of their country. Are these not the reason why Africa is regarded as "continent of ignorance, poverty, disease, misrule and corruption."7

\footnotetext{
${ }^{3}$ Sebastiane Ebatamehi, The Oldest Presidents in Africa 2018, (www.africanexponent.com, 2018). Retrieved 23/03/2019

${ }^{4}$ Ebatamehi, Ibid.

${ }^{5}$ Ebatamehi, Ibid.

${ }^{6}$ Yekeen Akinwale, President Buhari beats Yar'Adua's record- makes 172 day medical trips in two years, (www.icirnigeria.org. May 8, 2018). Retrieved on 9/4/2019

${ }^{7}$ Kealeboga J. Maphunye, Weaning African leaders off addiction to power is an ongoing struggle, (the conversation.com, 2018). Retrieved on 12/04/2019.
} 
Nigeria, for instance, has three stages in the educational formation of her citizens. She has primary, secondary and tertiary education. It is in the tertiary institution that one gets his first degree, Masters' degree and Ph.D degrees. Any leader that stopped in secondary school may not know the importance of tertiary education. Some of these African leaders have no tertiary institution degrees. The implication is that some of them do not have even first degrees. There is no doubt that any leader that is highly educated will never joke with the education of his populace for he knows the value. The performance of the educated will surely surpasses that of the uneducated for it is a fact that performance, intelligence and education are inseparable and are indispensable component of good leadership. ${ }^{8}$ The least educated president in Africa is Denis Sassou- Nguesso. He has absolutely and embarrassingly no degree. Joseph Kabila had only high school degree but at least unlike the least educated has improved himself apart from his high school degree. Isaias Afwerki of Eritrea is a secondary school drop-out. Only God knows what will be his relationship with teachers and children who attend school. Again Abdelaziz Bouteflika of Algeria has only secondary school education; even Paul Kagame of Rwanda has secondary school certificate. Muhammadu Buhari of Nigeria is also believed to have only secondary school certificate and every other education he must have received must have been ones he gained from military school just like other African leaders. These do not mean that we don't have African presidents who are highly educated. Hage Geingob of Namibia seem to be the most educated African leader for he has Bachelor of Arts from Fordham University, New York as well as Master of Arts in International Relations from Graduate Faculty of the New School, New York. ${ }^{9}$ There is no doubt that reasonability will be sine qua non in every action he takes. The educated would wish that the populace of their country will have access to education as well as other things that help people to live well in a community.

Both the uneducated, old, and sit tight presidents will affect either positively or negatively the destinies of the people that inhabit their respective countries. When we talk of destiny we mean somebody's preordained future, inner realizable purpose of life. ${ }^{10}$ A person's destiny "is everything that happens to them during their life, including what will happen in the future especially when it is considered to be controlled by someone or something else." ${ }^{11}$ The policies of every government affects the future of the youths of their country. If the leader is one who is selfish, i.e. always struggling only to satisfy himself or his family members, will automatically destroy the future of the youth populace of his country. For instance, if the leaders are only interested in medical trip oversees without trying to build such hospitals that attract them and their family members, there is every possibility that ordinary citizens cannot afford such a hospital. If

\footnotetext{
${ }^{8}$ Answers Africa, Top 10 Least Educated African Presidents at the Moment, (answerafrica.com). Retrieve on 23/03/2019

${ }^{9}$ Answers Africa, 10 Most Educated African Presidents, (answersafrica.com). Retrieved on 23/03/2019.

${ }^{10}$ Microsoft Encarta (2009), Destiny.

${ }^{11}$ Collins English Dictionary, Destiny: Definition and Meaning, (www.collinsdictionary.com). Retrieve on 23/03/2019
} 
they cannot afford it, it means that many will die young and thereby interrupting the wheel of their destiny that has already been set out to its destination.

In the same vein if the leaders would continually be sending their children and wards to study abroad, then they will never pay any serious attention to the country's educational system. They will not be ready to remunerate teachers, equip schools and colleges as well as tertiary institutions. The result is obvious. When a leader is only interested in sending out his children and that of the children of immediate family to study abroad it is a practical example of selfishness. It is only their children who will enjoy proper education and proper opportunities. Such selfishness is enough to destroy the destiny of the inhabitants of their respective countries. There is no pipe born water in most cities in Africa, but our leaders have no problem of their own drinking water. There is no steady and adequate supply of electric light but our leaders have steady supply of electric light which is being generated through the tax payers' contribution. There is no steady academic system in most African countries but the sons and daughters of our leaders are studying in Europe and America. In this way they selfishly make sure that leadership does not leave their respective families. Thus they will not allow any competition or rivalry to exist between their children and that of others in the country. It is this selfishness that Jesus addresses in Matt. 20:2428 .

Let us at this stage through historical critical method study the above passage to see how it would help us to proffer solutions on how to move the 54 countries of African forward. Historical critical study of Matt. 20:24-28 will help expose the causes of backwardness in Africa. It is not based on any other thing but on the selfishness of present crop of leaders in Africa.

\section{Exegesis of Matt. 20:24-28}

Chapter 20 of the Gospel according to Matthew which is the bigger unit that contains the subunit we want to study can comfortably be divided into four units, namely, verses 1-16 -the parable of the labourers in the vineyard; verses 17-19 is the prediction of the passion; verses 20-28 the passage of our study, shows the request of the sons of Zebedee and finally verses 29-34 deals with the healing of two blind men. Like we already stated, our exegesis is based on verses 20-28. This unit can also be divided into two sub units namely verses 20-23 which deals with the request made by the mother of Zebedee's sons and verses 24-28 deals with Jesus' teaching on leadership with service.

The remote context of verses $24-28$ is Jesus on his way to Jerusalem, remembering and sharing with his followers what was about to happen to him as he enters Jerusalem (verses 17-19). In a sense, he was trying to remind them that the time of his glorification was very close at hand, a period when he will actually assume his position as king after the mind of God. The immediate context of verses 24-28 is the request made by the mother of the two sons of Zebedee. It is as if the mother of the two sons of Zebedee overheard the instruction of Jesus to his followers and felt something has to be done for her children, hence, made her request. She knows what it means to 
be at either hands of Christ. It implies co-leadership. As Christ is praised, in her thinking, her children would be praised and ruled with him too. For her, wherever Christ rules her children should be at the head too. It was this context that provided Jesus the opportunity to teach and define what a true leader ought to be.

\section{Synoptic Tradition:}

As regards Matt. 20:24-28, its synopsis reveals that this chapter is part of what we call triple tradition. The implication is that it can be seen not only in Matthew but also in both Mark and Luke. Matthew and Mark are almost word for word whereas Luke varies so much.

\begin{tabular}{|c|c|c|}
\hline Matthew 20:24-28 & Mark 10:41-45 & Luke 22:24-27 \\
\hline $\begin{array}{l}\text { When the other ten heard this } \\
\text { they were indignant with the } \\
\text { two brothers. But Jesus called } \\
\text { them to him and said, "You } \\
\text { know that among the gentiles } \\
\text { the rulers lord it over them, } \\
\text { and great men make their } \\
\text { authority felt. Among you this } \\
\text { is not to happen. No; anyone } \\
\text { who wants to become great } \\
\text { among you must be your } \\
\text { servant, and anyone who } \\
\text { wants to be first among you } \\
\text { must be your slave, just as the } \\
\text { Son of man came not to be } \\
\text { served but to serve, and to } \\
\text { give his life as a ransom for } \\
\text { many." }\end{array}$ & $\begin{array}{l}\text { When the other ten heard this } \\
\text { they began to feel indignant } \\
\text { with James and John, so Jesus } \\
\text { called them to him and said to } \\
\text { them, "You know that among } \\
\text { the gentiles those they call } \\
\text { their rulers lord it over them, } \\
\text { and their great men make } \\
\text { their authority felt. Among } \\
\text { you this is not to happen. No; } \\
\text { anyone who wants to become } \\
\text { great among you must be your } \\
\text { servant, and anyone who } \\
\text { wants to be first among you } \\
\text { must be slave to all. For the } \\
\text { Son of man himself came not } \\
\text { to be served but to serve, and } \\
\text { to give his life as a ransom for } \\
\text { many." }\end{array}$ & $\begin{array}{l}\text { An argument also began } \\
\text { between them about who } \\
\text { should be reckoned the } \\
\text { greatest; but he said to them, } \\
\text { "Among the gentiles it is the } \\
\text { kings who lord it over them, } \\
\text { and those who have authority } \\
\text { over them are given the title } \\
\text { Benefactor. With you this } \\
\text { must not happen. No; the } \\
\text { greatest among you must } \\
\text { behave as if he were the } \\
\text { youngest, the leader as if he } \\
\text { were the one who serves. For } \\
\text { who is the greater: the one at } \\
\text { table or the one who serves? } \\
\text { The one at table, surely? Yet } \\
\text { here am I among you as one } \\
\text { who serves! }\end{array}$ \\
\hline
\end{tabular}

The context of the content of Matthew and Mark are similar but that of Luke appears to be different. In Luke's submission, Jesus spoke up because they were quarreling or arguing who would be the greatest among them. A closer look at the Gospel according to Luke reveals that Luke 22: 24-27 seems to be an insertion for it was not flowing directly from verses 21-23. A comparative study between the content of Matthew and Mark as well as Luke reveals that Mark named the two brothers to be James and John but Matthew and Luke paraphrased Mark without mentioning their names. Luke on his part never mentioned the context of the wife of Zebedee making a case for her two sons and as a result never made any reference to the sons of Zebedee. Again, in the parallel passage in Mark (10:35-45), it was the two sons themselves who made the request to Jesus not their mother for their mother was not really in the scene. But for Matthew (20:20-28), the mother of the sons of Zebedee took them to Jesus to make the request on their 
behalf. One wonders why the ten apostles, according to Matthew's gospel, were really angry with James and John instead of their mother. This fact of the anger of the ten betrays an editorial hand. These facts show that Matthew and Luke most likely must have relied on Mark in the composition of their gospels but arranged them according to the needs of their immediate communities. But in all, each of them is really discussing how a Christian leader must be. Mark made one clear point, and this is, that people can only be rulers when they have been regarded as such and are called to be so by the people. Luke on his part made it clear that, outside Christ, for one to be a ruler one must necessarily argue and struggle for it; but with Jesus, he stated how it will be. Among the believers, none will argue or struggle for it, it has to come easily for it will be given to one who will be ready to lower himself and serve, hence, service is a sign of greatness.

\section{Historical Critical Exegesis of Matt. 20:24-28}

Historical critical exegesis of the above text using the original language reveals that almost all the above verses have one critical problem or the other except verse $25 .^{12}$ Let us study them verse by verse. In verse 24 we have alternative reading of the words: kai akousantes (and hearing) by the following manuscripts $\sigma^{2}, \mathrm{~L}, \mathrm{Z}, \mathrm{Q}, \mathrm{f}^{13}, 33$, etc. They have akousantes de (but hearing); de (but) is a weaker form of alla (but); often having no stronger meaning than 'and'. It is used most often simply to provide a link with what has gone before. de cannot stand first in a clause or sentence, but is usually the second word. ${ }^{13}$ If that is anything to go by, it then means that what NestleAland has is the most plausible since using the alternative reading has nothing to add to the sentence.

Verse 26 presents us with alternative reading of a word and alternative reading of a phrase. On the alternative reading of a word, estai (it shall be) which is the 3rd person singular of future indicative of the verb "to be" eimi (I am) by the following manuscripts B, D, Z, 0281 and other minor manuscripts who have estin (it is) which is 3rd person singular, present indicative of the verb "to be" eimi (I am). Estai makes a better reading for Jesus was referring to what shall never happen among them in the nearest future when he will no longer be there with them. NestleAland is also strongly supported by original and ancient texts like $\sigma, C, L, W, Q$. Secondly we have alternative reading of the phrase "en humin megas genesthai" (among you becomes great). To understand this alternative reading better, let us number the above phrase 1.en 2.humin 3.megas 4.genesthai (1234). Some manuscripts like B and few manuscripts have 3124 - megas en humin genesthai (great among you becomes); others like C, (574) still have 3412 which is megas genesthai en humin ( becomes great among you); finally another group of manuscripts like pc $\left(\mathrm{ff}^{1}\right.$ ) have 1424 and hence dropping the 3rd word thus: en genesthai humin genesthai. This last group appears meaningless in its combination and the dropping of 'megas' but the rest mean the same if we are not doing literal translation but contextual translation. Still on this verse we have another

\footnotetext{
12 The write uses the Greek Text by Nestle-Aland,(1993). Novum Testamentum Graece, 27th Edition.

${ }^{13}$ Eric G. Jay, The New Testament Greek: An Introductory Grammar (Britain: University press,1987) p. 56
} 
alternative reading of a word- estai which we have explained above, by the following manuscripts $\sigma^{2}, \mathrm{~L}, \mathrm{~S}$ who have estō which means "to eat". A detail analysis shows that such is a scribal error which is part of aural mistakes (hearing one thing and writing another thing). What we have in the text stands, i.e. estai for there is no way esto could be the actual word used.

Verse 27 is another verse that has also two critical problems namely alternative reading of a word and alternative reading of a phrase. In our text we have ' $a n^{\prime}$ ' but some manuscripts like C,L,Z,Q, etc, has 'ean'. It is a fact that indefiniteness may be given to a pronoun or adverb by placing after it the particle 'an' or 'ean'; 'hos' means who, 'hos an' means whoever or whosoever. ${ }^{14}$ There is also an alternative reading of words 'en humin einai prōtos' (among you to be first) by W, and pc, have 1243 which is 'en humin prōtos einai. Still in this verse, there is also an alternative reading of a word estai by manuscripts like B, and G they have estō. See the explanation we offered in verse 26 above about estai.

Verse 28 has insertion by some manuscripts like D ( $Q$ it $\mathrm{vg}^{\mathrm{mss}} \mathrm{sy}^{\mathrm{c}}$ ). Some scholars believe that the insertion must have been derived from some apocryphal gospels. The insertion has reference to Luke 14:8-10. The insertion reads thus: umeis de zèteite ek mikrou auxēsai kai ek meizonos elatton einai. eiserchomenoi de kai paraklēthentes deipnēsai mē anaklinesthe eis tous exechontas topous, mēpote endoxoteros sou epelthē kai proselthōn o heithnoklētōr eipēn soi eti katō chōre, kai kataischunthēsē. ean de anapesēs eis ton èttona topon kai epelthē sou èttōn, erei soi o deipnoklētōr sunage eti anō, kai estai soi touto chrēsimon meaning: "But as for you, from littleness you seek to grow great and from greatness you make yourselves small. When you are invited to a banquet do not take one of the places of honour, because someone more important than you may arrive and then the steward will have to say, 'move down lower,' and you would be covered with confusion. Take the lowest place, and then if someone less important than you comes in, the steward will say to you, 'move up higher,' and that will be to your advantage." Considering the context we are handling in verses 24-28 it is very clear that adding it or allowing the insertion to be is superfluous. It takes one away from the theme under discussion though teaches humility, it does not involve service. So we allow our text as was preserved by the manuscripts Nestle-Aland consulted.

\section{Exegetical Interpretation of Matt. 20:24-28}

At this stage let us do verse by verse analysis to unravel what the eternal speaker had in mind. Verse 24 editorially introduced what happened when the request got to the hearing of the remaining apostles. As we said above their names were not mentioned but their mother was the one who made the request. Benedict T. Viviano argues that Matthew put the request in the mouth of their mother because he only had wanted to protect the honour of a hero of the Jewish

\footnotetext{
${ }^{14}$ Eric G. Jay, 212
} 
Christians - James. ${ }^{15}$ The present writer does not subscribe fully to the above. Matthew must have been putting into consideration the natural inclination of women. Women are naturally looking out for a way to make their children more exalted among other children. This fact is manifested in the life of Queen Bathsheba, the mother of Solomon, who went and pleaded on behalf of her son before king David for him to be made king over Israel (1 King 1:15-21). Something great happened as a result of that request from the caring mother (1Kings 1:28-31). Following from there, when the other ten heard the request of the mother of the two sons of Zebedee they were èganaktēsan "indignant" or "incensed" or "to make one extremely angry." The Greek word èganaktēsan is an aorist, from the verb aganateō which means "to be moved with indignation implies that they expressed their indignation." ${ }^{16}$ Aorist as we know is used to express a past action in an unqualified manner without really stating whether the action had been completed, still ongoing, repeated or how long it lasted. But is very clear in its usage in this verse that Jesus noticed their indignation. It was this scenario Luke was trying to capture when he said, "An argument also began between them ..." (Luke 22:24). Jesus was moved to douse the tension because he knows where such could lead if not nipped at the bud. Such an occasion of quelling the indignation of the ten of his followers helped him to teach an important lesson which this study is upholding- leadership that is manifested in service. One may wonder why this anger in the ten when they heard of the ambition of the two. It is not exaggeration to say that their anger originated from the fact that they all have that same ambition, the ambition to sit at either side of Jesus on his throne. This is because no one fights over what he does not know the value of. On this Adrian Leske says, "The idea that Jesus is soon to enter his kingdom leads 'the mother of the sons of Zebedee' to request that her sons James and John sit on the thrones of greater authority next to Jesus in his kingdom, thrones that the Twelve have heard will belong to them (Matt. 19:28)." ${ }^{17}$ I believe this is the root of their indignation.

In verse 25 , Jesus in an attempt to introduce model in leadership, taught his followers that there must be a difference between them and the gentiles or nations. The nation here stands for human community arranged or organized outside Christ. Among the gentiles or nations, leaders do two things, namely, they lord it over those they are ruling and also make their authority felt (i.e. they are tyrant leaders). As a good leader, Jesus called his followers to himself (proskalesamenos, this is another aorist used by the author which comes from the verb proskaleomai). Two words used in this verse to express the two heinous behaviours of gentile rulers include katakurieuousin which is 3rd person plural, present indicative active mood meaning to "lord it over." The word is a combination of kata and kurieuō which means in the New Testament, to bring under someone, master, overcome just as the evil one can hold one hostage (Acts 19:16), to domineer over

\footnotetext{
${ }^{15}$ Benedict T. Viviano, "The Gospel According to Matthew" in The New Jerome Biblical Commentary, (Britain: The Bath Press, 1997) p663.

${ }^{16}$ Fritz Rienecker, A Linguistic Key to the Greek New Testament, (Michigan: Grand Rapids, 1980) p60.

${ }^{17}$ Adrian Leske, "Matthew" in The International Bible Commentary (Bangalore: Theological Pub., 2004$)$ p1376.
} 
others. ${ }^{18}$ Anyone who domineers another is not doing that to improve the person's life but mostly for his selfish ends. Anyone who dominates makes his authority felt. The Greek that expresses that is kataxousiazousin, "have authority over". This is also 3rd person plural, present indicative, active mood which comes from the word kataxousiazō but when combined with genitive as we have in this verse (autōn), it means "to exercise authority over someone, to play the tyrant." ${ }^{19}$ One who plays the tyrant is one who is an absolute ruler, one who is authoritative, and who rules with absolute authority; not really answerable to any person. An absolute leader does what he likes most often ostensibly to bring peace to his country when in actual fact is working solely for his own welfare.

Verse 26 is parallel to verse 27. This points out that both portray the same information though verse 27 is more brunt. Verse 26 says, the greatest among you must become your servant; verse 27 says the first among you must be your slave. Verse 26 uses the noun diakonos (servant) whereas verse 27 uses the noun doulos (slave) both are mostly involved in rendering service for the welfare of others. Biblically, it is no exaggeration to claim that both mean the same or that one can stand for the other (Gen. 9:24; 24:9; Exod. 21:5; Matt. 10:24; Luke 17:7) though slave seems more derogatory in status when compared with a servant but basically they are the same. Verse 27 emphasizes the point Jesus started in verse 25 when he called his apostles very close to himself. A good leader is a servant to his community for when others are sleeping he is awake planning for their welfare and when they are running about for their personal needs, the servant leader is working tirelessly for the good of his people. A slave or one who serves knows that he does not have a permanent job. The implication is that his master (the led) has the power to hire and fire, hence, may decide to reject him (the leader) when he is no longer serving them well. This is in contrast to master-leader or despotic leader who will stop at nothing to maintain and perpetuate himself in the office. Put succinctly in these verses, "Jesus offers two other models of authority, free service and involuntary slavery, the second more radical than the first, but both important." 20 The mind of Jesus was really to provide alternative leadership, one contrary to the negative tendencies of the pagans (Matt. 5:47; 6:7; 18:17). He intended to proffer what is contrary to what was prevalent among the pagans. Jewish tradition recognized that most pagan rulers of post biblical times were apart from other negative tendencies, tyrants as well. ${ }^{21}$

The summit of his instruction and model he wants to leave for his disciples is seen in verse 28. Here he uses himself as the model when he says, "ho hios tou anthrōpou ouk èlthen diakonèthēnai alla diakonèsai kai dounai tēn psuchēn autou lupron anti pollōn." The son of man did not come to be served but to serve and to give his life as a ransom for many. The implication is that a good leader is one who will be ready to give up his life for the welfare of his subjects or citizens just as

\footnotetext{
${ }^{18}$ Wesley J. Perschbacher, (ed). The New Analytical Greek Lexicon, (Massachusetts: Hendrickson pub. 2004) p224

${ }^{19}$ Fritz Rienecker, p60.

${ }^{20}$ Viviano, p663.

${ }^{21}$ Craig S. Keener, The IVP Bible Background Commentary, New Testament, (Illinois: IVP Academic, 1993) p100.
} 
he himself is doing. The leader's rest depends on the wellbeing of the led. A good leader is one who can give his life as a lupron (ransom). Lupron is nothing but the prize paid for the release of a slave or slaves. The implication is that instead (anti) of people suffering or dying, the leader does it on behalf of the people. Jesus on this context, presented himself as a leader who came to pay the dept mankind incurred as a result of sin against God to appease God's wrath (Rom. 8:3-4; 1 Cor. 15:56; 2 Cor. 3:7, 9; Gal 3:13). Jesus with his life paid this ransom (1 Cor. 6:20; 7:23; Gal. 4:5). Thus Jesus presented himself as the suffering servant of Yahweh (Isa. 53) and at the same time an exemplary servant leader. Hence, he shows that what makes one great is service.

\section{African Leaders and Servant Leadership}

Jesus has given example with his own life, teaching them how a leader should labour among his people. This example he gave is what Pope Francis, the chief servant of the Christendom, extended to some African leaders he visited recently. On 12th April, for instance, he was with the factional leaders of Southern Sudan where he discovered that the leaders are in disarray and their indignation towards one another hampers the safety of their citizens as well as the development of Sudan. He taught them a lesson they would never forget by kissing their feet especially, President Salva Kiir Mayardit and opposition leader Riek Machar. The Pope lowered himself to the extent of kissing their feet to prove to them that they must do the same for one another. Leigh Mcmanus says, "Pope Francis knelt and kissed the feet of South Sudan's rival leaders in an unprecedented act of humbleness to encourage them to strengthen the African country's faltering peace process." ${ }^{22} \mathrm{He}$ did this to beg them not to return to civil war for Pope knows the implication of war on children and women and indeed on all.

African leaders as we have shown above are highly addicted to power. They do whatever is possible to remain in power so as to destroy the tenet of democratic ideals. Take for instance, Joseph Kabila of Democratic Republic of Congo was meant to step down in December 2016 but he refused to go despite all agitations. In the same vein Yoweri Museveni of Uganda, and Denis Sassou Nguesso of Congo are sitting tight without any desire to relinquish power. "Their refusal to step down at the appointed time flies in the face of several governance blueprints adopted as African countries shifted away from liberation politics to the new post independence struggle for democracy in the early 2000s." 23 They refuse to leave office because of their despotic and kleptomaniac tendencies. Former president of the US, B. Obama in 2015 said, "African's democratic progress is at risk when leaders refuse to step aside when their terms end." 24 It is a fact that "regular transfers of power give citizens hope that new policies, programs and approaches will be adopted by the new leadership." 25

\footnotetext{
22 Leigh Mcmanus, Exraordinary moment Pope Francis kneels to kiss the feet of rival South Sudan leaders. (www.dailymail.co.uk, 2019). Retrieved on 12/04/2019

${ }^{23}$ Leigh Mcmanus, ibid.

24 "Obama to African leaders: Step aside at end of terms" (www.pressreader.com). Retrieved on 12/04/2019

${ }^{25}$ Leigh Mcmanus, ibid.
} 
If the welfare of citizens is at the heart of African leaders, none will like to stay a day after their term. If their action is guided by service, they will be praying and waiting for the day they will leave office. But because majority of African leaders are selfish, corrupt, kleptomaniac, despotic, and power-addicted and power-drunk, they will never desire to leave office; even when they decide to leave, they will enthrone their stooges who will eventually cover their corrupt practices.

\section{Evaluation:}

In this write up we have been able to establish that African leaders hate the idea of relinquishing power once acquired. For them it must be permanent. There is nothing like servant leaders among African leaders, they are all masters and they lord it over their subjects. If the example of Jesus were to be followed by the present crop of leaders in Africa, Africa will develop beyond imagination. We have also established that there must be adequate academic qualification and age bracket in which one will be allowed to contest to rule. This is because the older one becomes, the weaker will the body system becomes and more friendlier he becomes with hospitals. Education is what a leader must be armed with before he can rule and rule well. The world is advancing daily with modern technologies, age of a leader and educational qualification must be in tandem with their counterparts all over the world. The model Jesus presented to his followers remains the most sustainable- service leads to greatness.

\section{Recommendation:}

- There must be age limit for an African president (ages 45-65 years)

- Doctorate degree should be made to be the minimum qualification of a would be African leader

- Organization of African Union (OAU) has to be reinvigorated to continue to serve as a peer review mechanism. OAU must have a way to discipline leaders who will be despotic and corrupt.

- A single tenure of six years is to be adopted by all the countries of Africa.

\section{Conclusion:}

African continent remains a country of backwardness, corrupt practices, ignorance on the part of leaders and the led, because African leaders are selfish, half educated, old, and stays very long in office, hence refusing to step aside and holding everybody to ransom. This work argues that if the content of Matt. 20:24-28 is imbibed by the present crop of African leaders, then Africa would be the envy of the committee of continents. 